\title{
sciendo

\section{The Impact of Parallel Energy Consumption on the District Heating Networks}

\author{
Eduard LATOSOV ${ }^{*}$, Anna VOLKOVA ${ }^{2}$, Andres SIIRDE ${ }^{3}$, Martin THALFELDT ${ }^{4}$, \\ Jarek KURNITSKI ${ }^{5}$ \\ ${ }^{1-5}$ Tallinn University of Technology, Ehitajate tee 5, Tallinn, 19086, Estonia
}

\begin{abstract}
The aim of this study is to evaluate and compare the impacts of heat recovery ventilation (HRV) and exhaust air heat pump (EAHP)-based solutions used in renovated buildings, which make it possible to reach performance class $\mathrm{C}$ in district heating (DH) area $\mathrm{CO}_{2}$ emissions, primary energy consumption and total energy costs for consumers. Evaluation is based on the methodology presented in the previous research paper [1]. Calculation results show that the use of EAHP has a negative impact on DH sustainability (heat losses in the DH network, DH heat price, reduced consumption of $\mathrm{DH}$ heat) and $\mathrm{CO}_{2}$ emissions related to energy delivery (heat and electricity) to consumers in the DH area. Positive aspects of the EAHP use include the fact that almost the same primary energy consumption level can be achieved with lesser (up to $7 \%$ ) annual costs (annual capital costs, DH heat costs and electricity costs) and lower initial investments (about $10 \%$ ). At the same time, every renovated building with EAHP will experience a negative impact on heat prices. In DH areas where almost all buildings are renovated with EAHP, cost savings are not as evident compared to buildings with HRV in DH areas where the use of parallel consumption solutions (EAHP) is minimized. It is reasonable to promote these renovation packages and solutions that benefit the building's primary energy reduction, and also do not increase electric energy consumption (additional electric power generators are needed) and do not damage DH networks.
\end{abstract}

Keywords - $\mathrm{CO}_{2}$ emissions; district heating; heat recovery ventilation; primary energy

\section{INTRODUCTION}

Improving building energy efficiency is considered to be one of the main measures for achieving climate goals, introduced in EU Roadmap for moving to a competitive low carbon economy in 2050 [2]. The reduction of building energy consumption is possible due to renovating heating and ventilation systems and the envelopes and it is common and to be expected. Improving the heating systems includes heat substation renovations, equipped with high operational security level and control possibilities, changing control unit and circulation pumps, that gives the possibility for the system to be flexible in heat delivery [3]. The natural ventilation system is changed by ventilation with heat recovery because natural ventilation leads to increased heat consumption in buildings [4], [5]. Renovation of the building envelope, including changing windows, renovation of walls, roof and the basics is also very important because it offers large potential for energy savings [6]. The increasing price of energy leads to the situation, that building energy efficiency improving works are growing all the time [7]. All above mentioned building refurbishment and heating/ventilation renovation solutions,

\footnotetext{
${ }^{*}$ Corresponding author.

E-mail address: eduard.latosov@ttu.ee
} 
which lead to heat demand reduction, have to be considered while planning and designing the DH elements, such as dimensioning the renovated DH networks and choosing the optimal capacity for new heat production units [8], [9]. The problem appears when during renovations the new heat energy sources are implemented, thus reducing the heat consumption from the DH system. When the heat consumer connected to the DH system also consumes heat produced by other energy sources, it leads to parallel energy consumption.

New energy efficiency standards, lead to renovation of existing buildings, including in the apartment building sector [10] which plays a significant role in reducing energy consumption and $\mathrm{CO}_{2}$ emissions. A significant amount of consumers in $\mathrm{DH}$ areas renovate buildings in order to reach performance class $\mathrm{C}$ (energy performance indicator (EPI) or calculated an nual primary energy (PE) consumption of $\leq 150 \mathrm{kWh} / \mathrm{m}^{2}[11]$ ), which is required by the Estonian renovation grant program in order to be eligible to receive a $40 \%$ return on renovation costs. Energy savings achieved in the buildings reconstructed with the support should reach $50 \%$ for apartment buildings in 2030 and $40 \%$ for small residential buildings.

It should be noted that for building energy performance determination primary energy index is used [12]. This index is based on primary energy factors (PEF) of energy carriers. The outcome of the building energy performance evaluation is impacted by PEF values. The definition of PE is energy that embodied in natural and has not undergone any engineered conversion or transformation (i.e. fossil fuels, solar, wind). Secondary energy is energy, transformed from PE, through energy conversion processes (i.e. electricity). PEF are used for the evaluation of the energy carriers, comparing them to the corresponding energy sources. PEF are determined coefficients, calculated as the inverse of the ratio between one unit of energy delivered to the building and $\mathrm{n}$ units of PE consumed to deliver it. For PEF calculation such factors, as energy utilization, required for energy carriers' transmission and distribution and conversion or transformation efficiency are taken into account. It means, that calculating the energy performance of a building not only the building aspects, but also the energy supply chain aspects are considered, when PE index is used. Primary energy factors are usually based on national or relevant European standards [13], [14].

EPI depends on the implementation of various integrated technical energy solutions (ITES) to achieve a certain energy consumption level, as well as the energy sources used. ITESs used in buildings which consume energy from nearby produced energy sources or other external networks (located outside of buildings, i.e., DH and cooling networks, power grids) will affect these networks.

It is very important to evaluate how energy efficiency measures in buildings influence district heating system [14]. In [15] the complexity of evaluating the influence of energy saving measures in buildings with district heating is discussed. In [16] it was analysed, how end user energy efficiency measures can influence energy efficiency of district heating CHP and boilers. The synergistic effect can be different (negative, positive or neutral).

Low heating carrier supply and return temperature are one of the main conditions that are required for future sustainable $4^{\text {th }}$ generation district heating [17]. Parallel energy consumption can arise as one of the barriers encountered by the existing DHS during the transition towards $4^{\text {th }}$ generation DH, due to high return temperatures [18]. Currently, two ventilation systems make it possible (EAHP and HRV) to achieve excellent energy efficiency and indoor climate. Gustafson et al. analysed HRV technology in terms of life cycle cost, discounted payback period, primary energy consumption, $\mathrm{CO}_{2}$ emissions and non-renewable energy consumption [19]. Thalfeldt et al. have studied how EAHP influence district heating energy use and return temperature [20]. 
EAHP and HRV are approved by the Estonian apartment building renovation grant program [21]. EAHP (which consumes a significant amount of electricity to drive the heat pump) is a preferable choice for Co-operative Housing because it allows reaching the EPI level required to obtain renovation grant with minimum investment costs [22].

The aim of this study is to evaluate the impacts of HRV and EAHP-based ITESs, which make it possible to reach performance class $\mathrm{C}$ in $\mathrm{DH}$ area. The evaluation is based on the approach for determining the effect of parallel consumption on the DH system, presented in the previous research paper [1].

This approach requires a comparison of changes in techno-economic parameters of the district heating network and buildings under the following conditions:

- Nearly all buildings connected to the DH network are rehabilitated/built in accordance with ITES without parallel consumption (basic conditions, basis for comparison);

- And vice versa, the use of alternative ITES is close to $100 \%$ (modified conditions).

\section{BASIC DH AREA CONDITIONS}

\subsection{Consumers}

Usually the consumers of DH network have various EPIs, energy consumption profiles and ITES. It acceptable is to use a common building type which prevails in a particular area. ITESs without or with a minimal parallel consumption (heat delivered from the grid, no local heat production from external energy sources exists) can be selected. This approach can be applied for parallel consumption evaluation both for existing buildings to be renovated and new planned users/consumers.

A significant portion of renovated buildings are supported by Estonia's national grant program (up to $40 \%$ of the eligible costs). To ensure maximum support for the rehabilitation, the building must comply with the following main conditions [21]:

- Performance class C (EPI $\left.\leq 150 \mathrm{kWh} / \mathrm{m}^{2}\right)$;

- $U$ value of exterior walls $\leq 0.22 \mathrm{~W} /\left(\mathrm{m}^{2} \mathrm{~K}\right), U$ value of roof $\leq 0.12 \mathrm{~W} /\left(\mathrm{m}^{2} \mathrm{~K}\right), U$ value of windows $\leq 1.10 \mathrm{~W} /\left(\mathrm{m}^{2} \mathrm{~K}\right)$;

- Use EAHP or HRV ventilation heat recovery;

- Assure constant air exchange rate $\geq 0.5 \mathrm{~h}^{-1}$ in apartments.

A standard 5-storey precast concrete building extensively manufactured during the period of 1960-1990 was used for this study. The building model, building data and modelling results for HRV (Option 1) and EAHP (Option 2)-based renovation packages are similar to the results presented in the previous research paper [20], where a dynamic simulation model IDA-ICE 4.7 [23] was used. For model simplifying a multiplier 3 was used for middle floor zones. It means that both the ventilation air and heating system water mass flow from respective zones was multiplied by 3. The internal horizontal slabs of the middle floor zones were adiabatic however it is a reasonable simplification because temperatures were similar at different floors. The building net area was $3519 \mathrm{~m}^{2}$ and heated area was $2968 \mathrm{~m}^{2}$.

The renovation ITES solutions are developed for HRV and EAHP. Renovation ITES solutions comply with the Estonia's national grant program conditions listed above. The main modelling results of the renovation packages are shown in Table 1. 
TABle 1. Modelling Results of RenOVAtion PACKAGES

\begin{tabular}{lll}
\hline Option & HRV & EAHP \\
\hline Efficiency/SCOP, $\% /-$ & 80 & 3.0 \\
Specific fan power, $\mathrm{kW} /\left(\mathrm{m}^{3} / \mathrm{h}\right)$ & 2.0 & 0.8 \\
Thermal transmittance of exterior walls, $\mathrm{W} /\left(\mathrm{m}^{2} \cdot \mathrm{K}\right)$ & 0.19 & 0.15 \\
Thermal transmittance of roof, $\mathrm{W} /\left(\mathrm{m}^{2} \cdot \mathrm{K}\right)$ & 0.11 & 0.08 \\
Thermal transmittance of window, $\mathrm{W} /\left(\mathrm{m}^{2} \cdot \mathrm{K}\right)$ & 1.1 & 0.9 \\
Domestic hot water tank, $\mathrm{m}^{3}$ & - & 1.5 \\
\hline
\end{tabular}

The energy demands and purchased energy data shows that EAHP increases the amount of energy emitted by radiators compared to a building with HRV (Fig. 1). Delivered and primary energy (PE, given in $\mathrm{kWh} / \mathrm{m}^{2}$ ) include building all energy requirements. The HRV is not equipped with a heat pump, EAHP does not have supply air heating. On the other hand, HRV had increased energy consumption by fans and supply air preheating during cold weather conditions. Energy consumption for domestic hot water and lighting is identical.

EAHP examples have increased total energy demand, but the purchased energy amount was smaller compared to the HRV example. The reason is because of the seasonal coefficient of performance (SCOP) for EAHP. However, initial PE in the EAHP case was higher (primary energy factor for electricity was 2.0 and for district heating 0.9 ) [24].
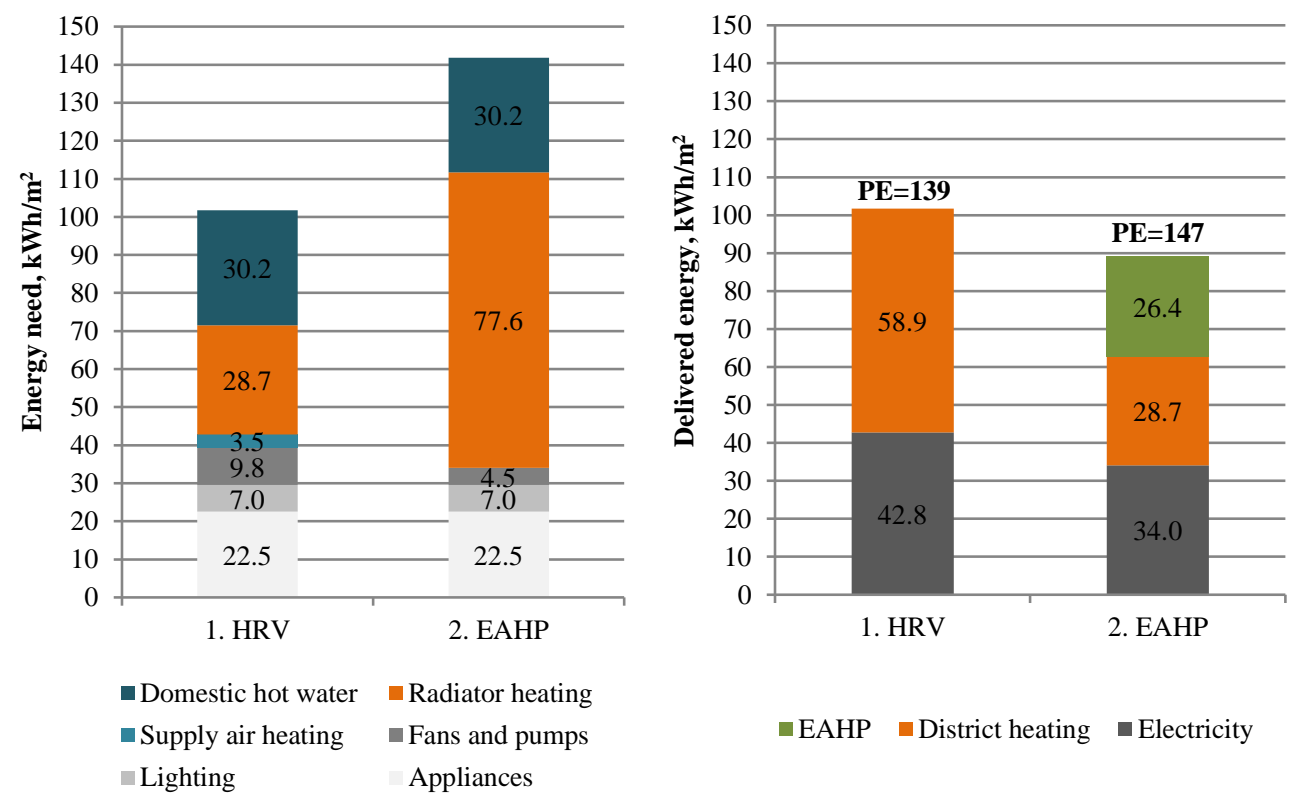

Fig. 1. Energy needs (demand) and initial delivered (purchased) and primary energy in the HRV (Option 1) and EAHP (Option 2) examples. 


\subsection{DH System Input Data and Assumptions}

For evaluation of parallel consumption, it is reasonable to select DH system properties which are typical for specific location. In Estonia, biomass (wood chips) boilers are common to cover the base load, and a natural gas or light fuel oil boiler for peak loads (we used natural gas for further calculations). DH network properties used for calculations are:

- Heat produced from wood chips $-85 \%$;

- Biofuel boiler average annual efficiency - $85 \%$ [25];

- Natural gas boiler average annual efficiency - $92 \%$ [25];

- Relative heat losses in the DH system - $15 \%$ [25];

- District heating price - 55 EUR/MWh;

- Share of fixed operating and maintenance costs (of the total heat price) - $45 \%$;

- Natural gas $\mathrm{CO}_{2}$ specific emissions - $0.198 \mathrm{tCO}_{2} / \mathrm{MWh}$ [26];

- Wood chips $\mathrm{CO}_{2}$ specific emissions set equal to zero [26].

Use of EAHP in Option 2 will decrease the consumption of DH heat and increase electric energy consumption.

To evaluate the impacts of increased electricity consumption, we used the following data:

- Electricity $\mathrm{CO}_{2}$ specific emissions - $1.1 \mathrm{tCO}_{2} / \mathrm{MWh}$ [27];

- Electricity price - 90 EUR/MWh.

\subsection{Calculations}

The main properties and values illustrating basic DH area conditions are shown in Table 2 . These values describe conditions where almost all consumers' buildings in the DH area are renovated in accordance with Option 1 (using HRV and parallel consumption minimized), and the number of buildings renovated using Option 2 (the EAHP case) is negligible. Thus, we assume that the impact of Option 2 on heat prices and heat losses is also negligible.

TABLE 2. SPECIFICATION OF BUILDINGS RENOVATED

ACCORDING TO OPTION 1 (ALMOST ALl CONSUMERS) AND OPTION 2 (Negligible Amount of CONSUMERs) Under BASIC DH AREA CONDITIONS

\begin{tabular}{llll}
\hline No. & Parameter & $\begin{array}{l}\text { Option } 1 . \\
\text { HRV }\end{array}$ & $\begin{array}{l}\text { Option } 2 . \\
\text { EAHP }\end{array}$ \\
\hline A.1 & Heated area of the building, $\mathrm{m}^{2}$ & 2968 & 2968 \\
A.2 & Amount of heat purchased from DH per annum, $\mathrm{kWh} / \mathrm{m}^{2}$ & 59 & 29 \\
A.3 & Annual electricity consumption, $\mathrm{kWh} / \mathrm{m}^{2}$ & 43 & 60 \\
A.4 & Amount of heat purchased from DH per annum [A.1·A.2/1000], MWh & 175 & 85 \\
A.5 & Amount of electric energy purchased per annum [A.1·A.3/1000], MWh & 127 & 179 \\
A.6 & DH heat price, EUR/MWh & 55 & 55 \\
A.7 & DH heat purchase cost [A.4·A.6], EUR & 9615 & 4685 \\
A.8 & Share of fixed operating and maintenance costs (of the total DH heat price) & $45 \%$ & \\
A.9 & Fixed DH operating and maintenance costs [A.7·A.8], EUR & 4327 & 4327 \\
A.10 & Electricity price, EUR/MWh & 90 & 90 \\
A.11 & Electricity costs [A.5·A.10], EUR & 11433 & 16134 \\
A.12 & Energy costs [A.7+A.11], EUR & 21048 & 20819 \\
\hline
\end{tabular}




\begin{tabular}{|c|c|c|c|}
\hline No. & Parameter & $\begin{array}{l}\text { Option } 1 . \\
\text { HRV }\end{array}$ & $\begin{array}{l}\text { Option } 2 . \\
\text { EAHP }\end{array}$ \\
\hline A.13 & Renovation costs, EUR & 445000 & 400000 \\
\hline A. 14 & Renovation annual capital costs, EUR & 35708 & 32097 \\
\hline A. 15 & Total costs [A.12+A.14], EUR & 56756 & 52916 \\
\hline A.16 & Relative heat losses in the DH network & $15 \%$ & $15 \%$ \\
\hline A. 17 & Heat delivered to the DH network [A.4/(A.1-A.16)], MWh & 206 & 100 \\
\hline A. 18 & Absolute heat losses in the DH network [A.16.A.17], MWh & 31 & \\
\hline A. 19 & Variable cost of heat production [(A.7-A.9)/A.17], EUR/MWh & 26 & 26 \\
\hline A. 20 & Share of renewable fuels in the DH heat production & $85 \%$ & $85 \%$ \\
\hline A. 21 & DH heat generated from renewable fuels [A.17·A.20], MWh & 175 & 85 \\
\hline A. 22 & DH heat generated from fossil fuels [A.17-A.21], MWh & 31 & 15 \\
\hline A. 23 & Natural gas $\mathrm{CO}_{2}$ specific emissions, $\mathrm{tCO}_{2} / \mathrm{MWh}$ & 0.198 & 0.198 \\
\hline A. 24 & Electricity $\mathrm{CO}_{2}$ specific emissions, $\mathrm{tCO}_{2} / \mathrm{MWh}$ & 1.1 & 1.1 \\
\hline A. 25 & Natural gas boiler average annual efficiency & $92 \%$ & $92 \%$ \\
\hline A. 26 & $\mathrm{CO}_{2}$ emissions from fossil fuel combustion in DH [A.22.A.23/A.25], $\mathrm{tCO}_{2}$ & 6.6 & 3.2 \\
\hline A. 27 & $\mathrm{CO}_{2}$ emissions from electric power generators used [A.5- A.24], $\mathrm{tCO}_{2}$ & 140 & 197 \\
\hline A. 28 & $\mathrm{CO}_{2}$ emissions from consumed energy [A.26+A.27], $\mathrm{tCO}_{2}$ & 146 & 200 \\
\hline
\end{tabular}

Some clarifications on the structure of Table 2 are as follows:

- An equation to calculate an appropriate parameter value is shown in square brackets. Values related to other parameters are linked with appropriate parameter numbers and marked in bold, italic text in the equation;

- Parameters which use values described in other sections of this paper;

- Annual capital costs are calculated based on annuity payback and assuming that the money source for the renovation work is a loan with the annual loan cost ratio of $5 \%$ and a 20 -year loan term.

Renovation costs used in the calculations (Table 2, parameter 13) are based on price lists obtained from construction companies for Option 1 and Option 2 renovation packages of a standard 5-storey precast concrete building.

\section{Modified DH AREA CONDITIONS}

The main properties and values illustrating modified DH area conditions are shown in Table 3. These values describe conditions where almost all consumers' buildings in the DH area are renovated in accordance with Option 2 (using EAHP, and parallel consumption is maximized), and the share of buildings renovated using Option 1 (the HRV case) is negligible. 


\section{TABLE 3. SPECIFICATION OF CONSUMERS' BuILDINGS RENOVATED ACCORDING TO OPTION 1 (NEGLIGIBLE AMOUNT OF CONSUMERS) AND OPTION 2 (ALMOST ALL CONSUMERS) UNDER MODIFIED DH AREA CONDITIONS}

\begin{tabular}{llll}
\hline No. & Parameter & $\begin{array}{l}\text { Option } 1 . \\
\text { HRV }\end{array}$ & $\begin{array}{l}\text { Option } 2 . \\
\text { EAHP }\end{array}$ \\
\hline B.1 & Relative heat losses in the DH network & $27 \%$ & $27 \%$ \\
B.2 & Heat delivered to the DH network [A.4/A.1-B.1], MWh & 116 & 238 \\
B.3 & DH heat price [(B.2.A.19+A.8)/A.4], EUR/MWh & 86 & 86 \\
B.4 & DH heat purchase cost [B.3.A.4], EUR & 7310 & 15002 \\
B.5 & Total costs [A.11+A.14+B.3], EUR & 55541 & 62143 \\
B.6 & DH heat generated from renewable fuels [A.20·B.2], MWh & 99 & 202 \\
B.7 & DH heat generated from fossil fuels [B.2-B.6], MWh & 17 & 36 \\
B.8 & $\mathrm{CO}_{2}$ emissions from fossil fuel combustion in DH [A.23.B.7/A.25], $\mathrm{tCO}_{2}$ & 4 & 8 \\
B.9 & $\mathrm{CO}_{2}$ emissions from electric power generators used [A.27], $\mathrm{tCO}_{2}$ & 197 & 140 \\
B.10 & $\mathrm{CO}_{2}$ emissions from consumed energy [B.8+B.9], tCO & 201 & 147 \\
\hline
\end{tabular}

If Option 2 prevails in building renovations, it will affect heat prices and heat delivery from the boiler station. Heat prices will increase because fixed heat production, operating and maintenance costs (absolute values) will remain the same, while the share of fixed costs will increase due to reduced heat consumption in the DH network.

Some clarifications on the structure of Table 3 are as follows:

- Reduction of heat consumption in the DH network means that relative heat loss in the DH network will be increased because the absolute value of heat losses will remain the same. For basic DH area conditions (most buildings are renovated according to Option 1) relative DH losses constitute $15 \%$ or $31 \mathrm{MWh}$ as an absolute value for a typical renovated 5-story large-panel concrete apartment building (Table 2, parameter 18). If we increase the share of buildings renovated according to Option 2 (modify DH area conditions for a renovation solution with a higher parallel consumption rate), then the heat consumption from DH network will be $85 \mathrm{MWh}$ annually and relative heat losses will constitute $27 \%$;

- DH heat price is calculated based on Option 2 related data and is also valid for Option 1.

\section{COMPARISON}

Fig. 2, Fig. 3, Fig. 4 and Fig. 5 illustrate the impact of an increased share of implementing Option 2 building renovation solution (use of EAHP with high parallel consumption) on buildings and the DH network, compared to basic DH area conditions, where almost all buildings are rehabilitated in accordance with Option 1 (HRV without parallel consumption) and the share of buildings renovated using Option 2 (EAHP case) is negligible. Thus, we assume that the impact of Option 2 on heat prices and heat losses is also negligible. The figures below are based on calculations provided in Table 2 and Table 3. 


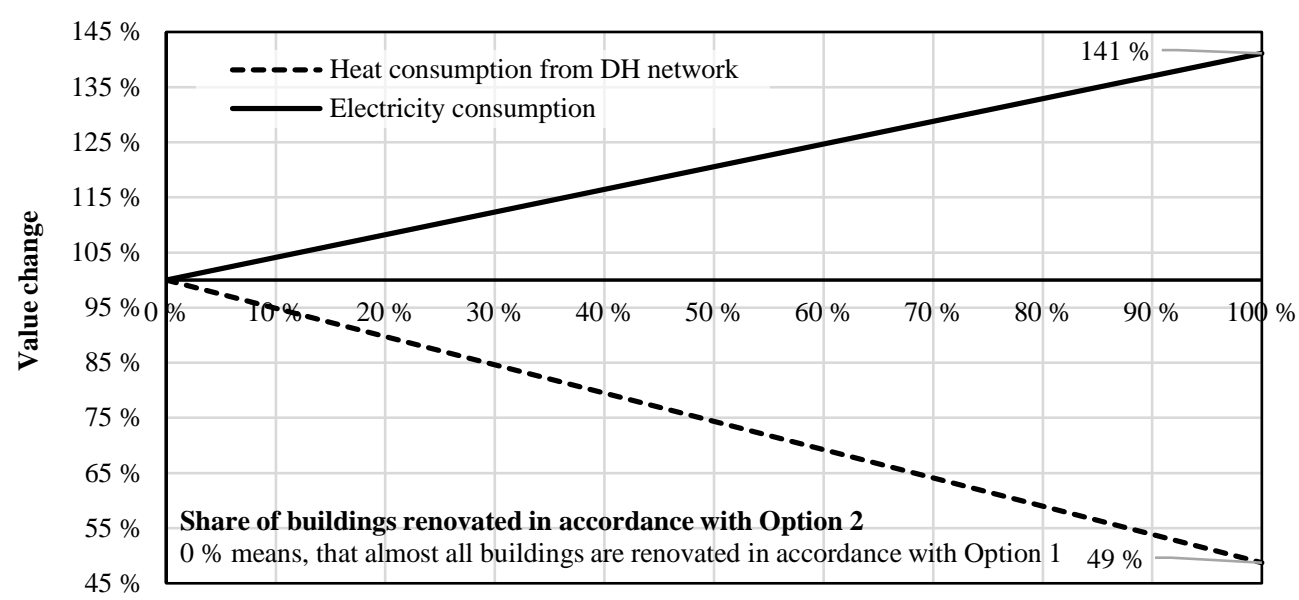

Fig. 2. Impact of an increased share of Option 2 building renovation solution implementation on heat consumption in the DH network and electric energy consumption.

Fig. 2 shows that choosing Option 2 renovation solution will significantly decrease the consumption in the DH. If Option 2 is the primary renovation solution, heat consumption in the $\mathrm{DH}$ area will be reduced by half. At the same time, electricity consumption will increase by $40 \%$ in comparison to Option 2 solution.

Reduction of heat consumption in the $\mathrm{DH}$ area in case of an increased share of Option 2 implementation will have a negative effect on the DH network's relative heat losses and heat prices (Fig. 3). These effects are more profound when the share of buildings renovated in accordance with Option 2 is larger. Based on assumptions and the initial data used in this article, relative heat losses in the DH network will increase from $15 \%$ (100\% renovated in accordance with Option 1) to $27 \%$ (100\% renovated in accordance with Option 2). Heat price will increase by more than $55 \%$ (from 55 EUR/MWh up to 86 EUR/MWh).

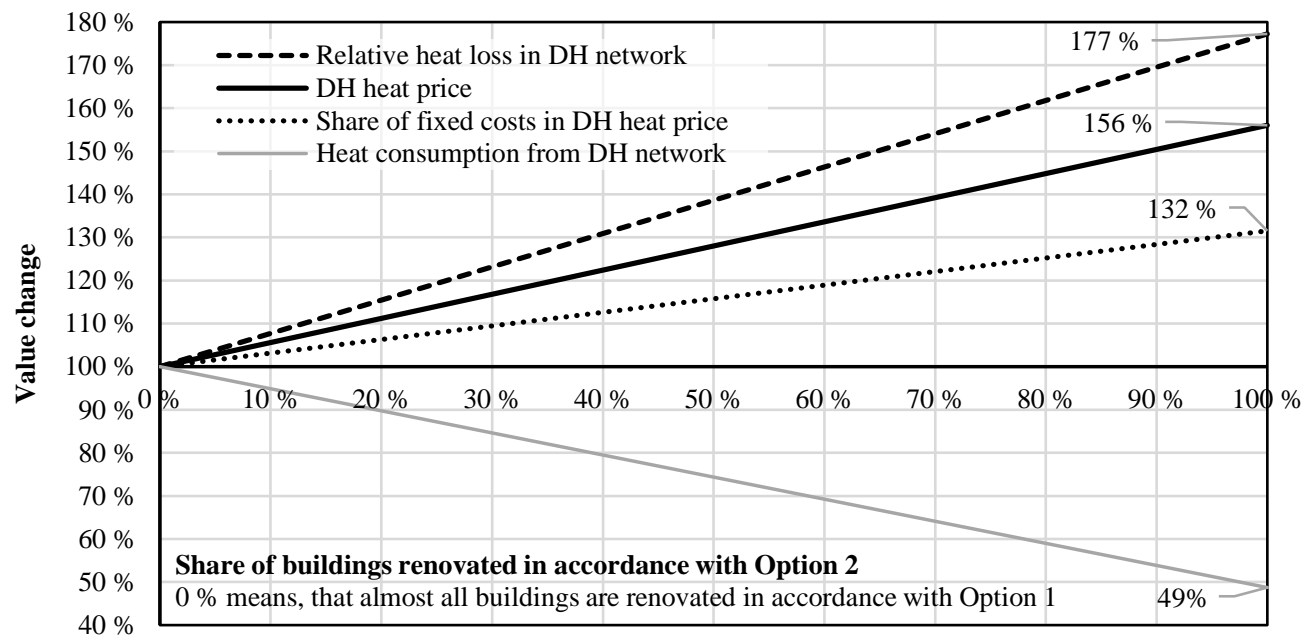

Fig. 3. Impact of an increased share of Option 2 building renovation solution implementation on relative heat loss, DH heat prices, the share of fixed costs of the DH heat price and heat consumption. 
$\mathrm{CO}_{2}$ emissions from electric power generated and $\mathrm{CO}_{2}$ emissions from fossil fuel combustion in $\mathrm{DH}$ depend on the share of fuels used for heat generation, their $\mathrm{CO}_{2}$ specific emissions and electricity specific emission. Based on assumptions and initial data, the increase in Option 2 implementation in building renovations will increase $\mathrm{CO}_{2}$ emissions up to $40 \%$ (electricity consumption's $\mathrm{CO}_{2}$ specific emission is about 5 times higher than that of natural gas). The impact of an increased share of Option 2 building renovation solution implementation on $\mathrm{CO}_{2}$ emissions from energy production (DH heat and electricity) is presented in Fig. 4.

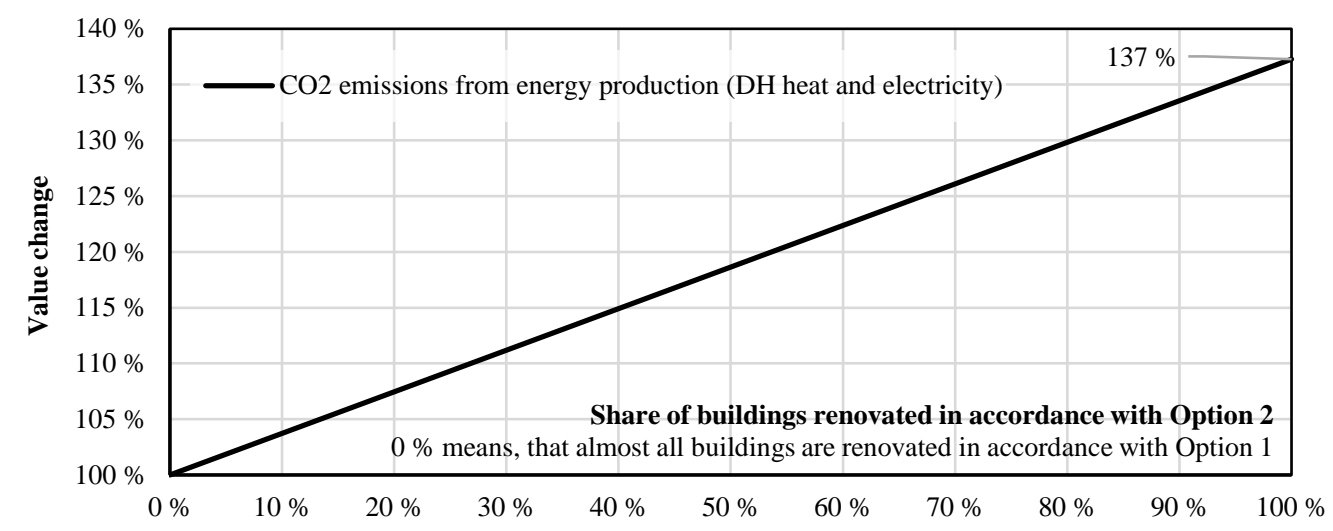

Fig. 4. Impact of an increased share of Option 2 building renovation solution implementation on $\mathrm{CO}_{2}$ emissions from energy production (DH heat and electricity).

Fig. 5 shows impacts of an increased share of Option 2 building renovation solution implementation on annual capital and energy costs for buildings renovated in accordance with Option 1 and Option 2.

In general, the use of Option 2 will lower annual costs. However, an increase in the number of buildings renovated based on Option 2 will increase heat prices and total annual costs. This means that if the share of buildings renovated using Option 2 (with EAHP) is small, and then these buildings will benefit from cost reduction; however, each additional building renovated with Option 2 will reduce this difference, compared to a situation where almost all buildings are renovated based on Option 1.

The total annual costs for consumers in the DH area where a majority of buildings are renovated based on Option 2 will be almost the same as the costs for buildings renovated in accordance with Option 1 where parallel consumption is minimized (i.e., almost all buildings are renovated based on Option 1). 


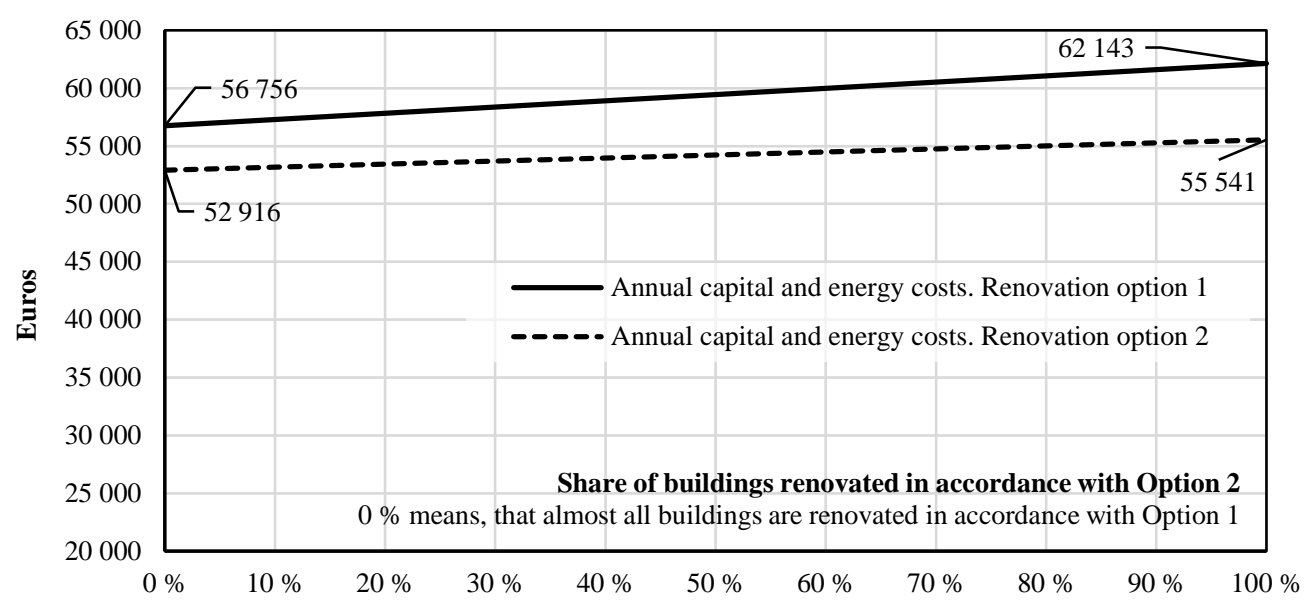

Fig. 5. Impact of an increased share of Option 2 building renovation solution implementation on annual capital and energy costs for buildings renovated in accordance with Option 1 and Option 2.

A summary of impacts related to the use of renovation solutions based on EAHP (Option 2), compared to basic DH area conditions (i.e., almost all buildings are renovated in accordance with Option 1) for the DH network and DH area buildings can be found below. Calculated values are valid for the DH area which is defined by the same preconditions and assumptions as described in this article. Positive impacts include:

- The $40 \%$ return on renovation costs provided by Estonian renovation grant program can be received with a considerably smaller investment (around $10 \%$ ), as compared to the renovation solution based on HRV. Exact values for real buildings may vary;

- A nearly identical primary energy consumption level can be achieved with reduced (up to $7 \%$ ) annual costs (annual capital costs, DH heat costs and electricity costs).

Negative impacts include:

- Electricity consumption will increase up to $41 \%$;

- Relative heat losses in the DH network will increase up to $90 \%$ (from $15 \%$ to $27 \%$ );

- The use of Option 2 will increase $\mathrm{CO}_{2}$ emissions related to energy production for the $\mathrm{DH}$ area buildings by $37 \%$. The reason for that is the fact that EAHP consumes a significant amount of electricity in order to drive the heat pump, and electricity has a high $\mathrm{CO}_{2}$ emission factor;

- A decrease in heat consumption in the DH network will increase DH heat prices. The total annual costs for consumers in the $\mathrm{DH}$ area, where almost all buildings are renovated based on Option 2, will be almost the same, as the costs for consumers who live in buildings renovated in accordance with Option 1, where parallel consumption is minimized (i.e., almost all buildings are renovated based on Option 1).

\section{SUMMARY AND DISCUSSION}

The use of EAHP has a negative impact on the DH sustainability (relative heat losses in the DH network, DH heat prices, consumption reduction) and $\mathrm{CO}_{2}$ emissions related to energy delivery (heat and electricity) to the DH area consumers. 
Positive aspects of EAHP use include the fact that nearly the same primary energy consumption level can be achieved with reduced (up to $7 \%$ ) annual costs (annual capital costs, $\mathrm{DH}$ heat costs and electricity costs) and smaller initial investments (about $10 \%$ ). At the same time, every building renovated with EAHP will have a negative impact on heat prices. In the $\mathrm{DH}$ areas where almost all buildings are renovated with EAHP, the cost savings are not as evident compared to buildings with an HRV in the DH areas, where the use of parallel consumption solutions (EAHP) is minimized. The total annual costs for consumers in the DH area where a majority of buildings are renovated based on EAHP will be almost the same as the costs for buildings renovated with HRV.

In case of combined heat and power (CHP) usage in the DH network, additional negative effects will appear. CHP can operate over longer periods with partial loads, when electrical energy efficiency coefficient is lower, leading to reduced CHP electricity-to-heat ratio. In these circumstances CHP operation can become unprofitable. In additions when heat load is below the required minimum, it is not possible to keep CHP working in operation regime. HRV and EAHP based parallel energy consumption increasing leads to the situation, when summer DH heat load is reduced or even excluded. At the same time winter heat load peaks remain relatively at the same level and DH operator should cover these peaks.

It is reasonable to promote these renovation packages and solutions that benefit the building's primary energy reduction, and also do not increase electric energy consumption (additional electric power generators are needed), and do not damage DH networks.

\section{ACKNOWLEDGMENTS}

This work was supported by Estonian Ministry of Education and Research (base funding project B55) and by the Estonian Centre of Excellence in Zero Energy and Resource Efficient Smart Buildings and Districts, ZEBE, grant 2014-2020.4.01.15-0016 funded by the European Regional Development Fund.

\section{REFERENCES}

[1] Latosov E., Volkova A., Siirde A., Kurnitski J., Thalfeldt M. Methodological approach to determining the effect of parallel energy consumption on district heating system. Environmental and Climate Technologies 2017:19:5-14. doi:10.1515/rtuect-2017-0001

[2] Blumberga A., Cilinskis E., Gravelsins A., Ferrao P., Le O. Analysis of regulatory instruments promoting building energy efficiency. Energy Procedia 2018:147:258-267. doi:10.1016/j.egypro.2018.07.090

[3] Augustins E., Jaunzems Dz., Rochas C., Kamenders A. Managing energy efficiency of buildings: analysis of ESCO experience in Latvia. Energy Procedia 2018:147:614-623. doi:10.1016/j.egypro.2018.07.079

[4] Zogla G., Blumberga A. Energy Consumption and Indoor Air Quality of Different Ventilation Possibilities in a New Apartment Building. Environmental and Climate Technologies 2010:4:130-135. doi:10.2478/v10145-010-0028-1

[5] Andric I., Pina A., Ferrao P., Fournier J., Lacarriere B., Le Corre O. Assessing the feasibility of using the heat demandoutdoor temperature function for a long-term district heat demand forecast. Energy Procedia 2017:132:963-968. doi:10.1016/j.egypro.2017.05.093

[6] Ilomets S., Kuusk K., Paap L., Arumagi E., Kalamees T. Impact of Linear Thermal Bridges on Thermal Transmittance of Renovated Apartment Buildings. Journal of Civil Engineering and Management 2017:23(1):96-104. doi:10.3846/13923730.2014.976259

[7] Zagorskas J., Kazimieras E., Turskis Z., Burinskien M., Blumberga A., Blumberga D. Thermal insulation alternatives of historic brick buildings in Baltic Sea Region. Energy and Buildings 2014:78:35-42. doi:10.1016/j.enbuild.2014.04.010

[8] Delmastro C., Martinsson F., Dulac J., Corgnati S. P. Sustainable urban heat strategies: Perspectives from integrated district energy choices and energy conservation in buildings. Case studies in Torino and Stockholm. Energy 2017:138:1209-1220. doi:10.1016/j.energy.2017.08.019

[9] Aberg M., Henning D. Optimisation of a Swedish district heating system with reduced heat demand due to energy efficiency measures in residential buildings. Energy Policy 2011:39(12):7839-7852. doi:10.1016/j.enpol.2011.09.031 
[10] Zagorskas J., Paliulis G. M., Burinskiene M., Venckauskaite J., Rasmussen T. V. Energetic refurbishment of historic brick buildings: Problems and opportunities. Environmental and Climate Technologies 2013:12(1):20-27. doi:10.2478/rtuect-2013-0012

[11] Kuusk K., Kalamees T. Estonian grant scheme for renovating apartment buildings. Energy Procedia 2016:96:628-637. doi:10.1016/j.egypro.2016.09.113

[12] Leoncini L. The Primary Energy Factors play a central role in European 2020 targets achievement. Policies for Sustainable Construction 2016:113-120.

[13] EU Directive 2010/31/EU of the European Parliament and of the Council of 19 May 2010 on the energy performance of buildings (recast). Official Journal of the European Union 2010:13-35.

[14] Pakere I., Romagnoli F., Blumberga D. Introduction of small-scale $4^{\text {th }}$ generation district heating system. Methodology approach. Energy Procedia 2018:149:549-554. doi:10.1016/j.egypro.2018.08.219

[15] Gustavsson L., Dodoo A., Truong N. L., Danielski I. Primary energy implications of end-use energy efficiency measures in district heated buildings. Energy and Buildings 2011:43(1):38-48. doi:10.1016/j.enbuild.2010.07.029

[16] Le Truong N., Dodoo A., Gustavsson L. Effects of heat and electricity saving measures in district-heated multistory residential buildings. Applied Energy 2014:118(1):57-67. doi:10.1016/j.apenergy.2013.12.009

[17] Ziemele J., Cilinskis E., Zogla G., Gravelsins A. Impact of economical mechanisms on $\mathrm{CO}_{2}$ emissions from non ETS district heating in Latvia using system dynamic approach. International Journal of Energy and Environmental Engineering 2018:9(2):111-121. doi:10.1007/s40095-017-0241-9

[18] Volkova A., Masatin V., Siirde A. Methodology for evaluating the transition process dynamics towards 4th generation district heating networks. Energy 2018:150(1):253-261. doi:10.1016/j.energy.2018.02.123

[19] Gustafsson M., Gustafsson M. S., Myhren J. A., Bales C., Holmberg S. Techno-economic analysis of energy renovation measures for a district heated multi-family house. Applied Energy 2016:177(1):108-116. doi:10.1016/j.apenergy.2016.05.104

[20] Thalfeldt M., Kurnitski J., Latosov E. Exhaust air heat pump connection schemes and balanced heat recovery ventilation effect on district heat energy use and return temperature. Applied Thermal Engineering 2018:128(5):402414. doi:10.1016/j.applthermaleng.2017.09.033

[21] RT I 24.03.2015 2, Korterelamute rekonstrueerimise toetuse andmise tingimused, Estonian Ministry of Economy and Communications Ordinance, 2015.

[22] Thalfeldt M., Kurnitski J., Latosov E. The Effect of Exhaust Air Heat Pump on District Heat Energy Use and Return Temperature. CLIMA 2016 - proceedings of the 12th REHVA World Congress: Volume 3. Aalborg: Aalborg University, 2016.

[23] Software IDA-ICE. IDA Indoor Climate and Energy 4.7.

[24] Energiatohususe miinimumnouded [In Estonian]. Estonian Ministry of Economy and Communications Ordinance No. 55, 03.06.2015.

[25] Estonian Competition Authority. Soojuse piirhinna kooskolastamise pohimotted [In Estonian]. Tallinn, 2013.

[26] Valisohku valjutatava susinikdioksiidi heite arvutusliku maaramise meetodid [In Estonian]. Riigi Teataja, 2017.

[27] Uiga J. $\mathrm{CO}_{2}$ emissions resulting from Final Energy Consumption - A Case Study of Tartu City. Estonian University of Life Sciences, Tartu, 2014.

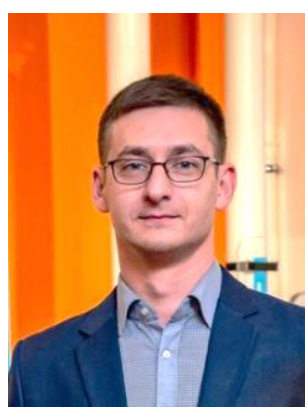

Eduard Latosov, Ph. D., assistant professor in Department of Energy Technology, Tallinn University of Technology. He defended Ph. D. thesis in 2011, in Tallinn University of Technology. Starting from 2015 he works in the Department of Energy Technology, Tallinn University of Technology (Estonia). Eduard Latõšov is author and co-author of more than 20 scientific publications. The main research topics are district heating, CHP, primary energy and energy efficiency. 3723359298, Ehitajate tee 5, 19086, Tallinn, Estonia. ORCID ID: https://orcid.org/0000-0002-2085-4471 

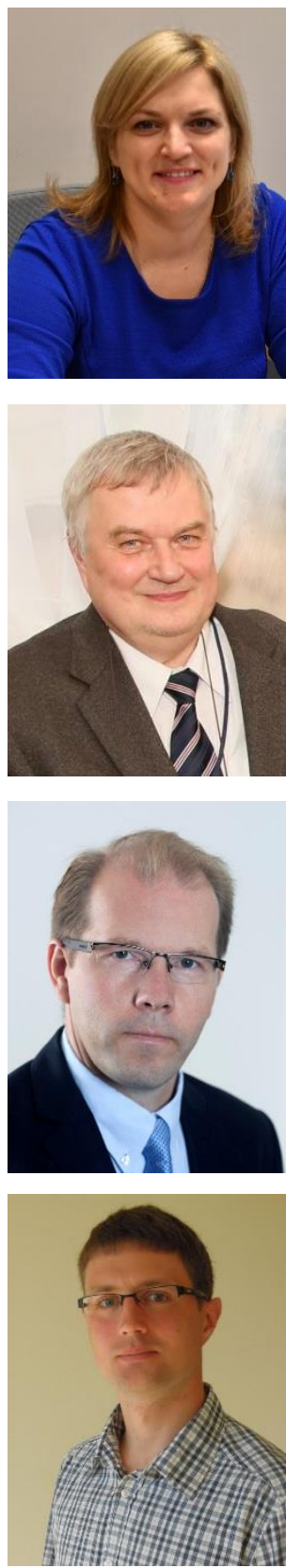

Anna Volkova, Dr.sc.ing. senior researcher in Department of Energy Technology, Tallinn University of Technology. She defended Ph. D. thesis in 2008, in Riga Technical University (Latvia). Anna Volkova has been as a postdoc researcher and later senior researcher since 2009 in Department of Energy Technology, Tallinn University of Technology (Estonia). Anna Volkova is author and co-author of more than 30 scientific publications. The main research topics are district heating, thermal energy storage, CHP and energy efficiency. ORCID ID: https://orcid.org/0000-0002-3802-3510

Andres Siirde Ph. D., professor, Director of Department of Energy Technology of the Tallinn University of Technology. He received Industrial Thermal Power Engineer Diploma (1980) and doctoral degree (1984). The main research areas are oil shale, cogeneration, SEG emissions, and energy efficiency. A. Siirde has been a part of academic staff of TUT since 1984. A. Siirde is author of more than 70 publications.

ORCID ID: https://orcid.org/0000-0002-2352-6983

Jarek Kurnitski, Ph. D., professor in Energy Performance of Buildings and Indoor Climate at Tallinn University of Technology. He received Ph. D. in Helsinki University of Technology in 2000. Since April 2012 Jarek is the leader of Nearly Zero Energy Buildings nZEB research group at TUT. From 2009 to the end of 2012 he was Senior Lead in the Energy Programme for SITRA, the Finnish Innovation Fund.

ORCID ID: https://orcid.org/0000-0003-3254-0637

Martin Thalfeldt, Ph. D., expert in Department of Civil Engineering and Architecture at Tallinn University of Technology and Post-Doc in Norwegian University of Science and Technology. He received Ph. D. in Tallinn University of Technology Faculty of Civil Engineering, Department of Environmental Engineering in 2016.

Martin Thalfeldt is author and co-author of more than 30 scientific publications. The main research topics are HVAC systems, energy efficiency, NZEB, renovation of apartment buildings.

ORCID ID: https://orcid.org/0000-0002-9414-2514 